\title{
言語音と非言語音の受聴
}

\begin{abstract}
重野純
要 約：言語音と非言語音の知覚には種々の差異がある. 3 つの純音を継時提示すると, 第 2 音の高さは時間的に接近した音へ同化的に知覚される(聴覚的夕ウ効果). 実験 1 は聴覚的夕 ウ効果について, 言語音 (合成母音) と非言語音（純音）の場合を比較した。純音では聴覚的 夕ウ効果が認められたが, 合成母音では時間的に接近する音へ対比が生じた。これを「逆夕ウ 効果」と名付けた．カテゴリー判断の習熟度の低い純音の場合は高さについての聴覚的記憶が 利用されるのに対して, 習熟度の高い合成母音の場合はカテゴリー的記憶が利用されやすいた めと考えた. 実験 2 は 3 音のカテゴリー関係が日常会話において同・異の場合を調べた. 結果 は, 母音のカテゴリーが同 $\rightarrow$ 異へ連続的に変化すると, 知覚も同化 $\rightarrow$ 対比へ連続的に変化した。 言語音と非言語音の知覚が異なるのは, 物理的性質の違いよりもむしろ, カテゴリー判断の習 熟度などのきき手側の要因によることが示唆された。
\end{abstract}

索引用語：聴覚的夕ウ効果，同化，対比，聴覚的記憶，カテゴリー的記憶

\section{Perception of Speech and Nonspeech Sounds}

\section{Sumi Shigeno}

\begin{abstract}
It has been reported in various experimental situations that the perception of speech and nonspeech are different. When three tones are presented successively, the pitch of the second tone is perceived to be similar to the tone that is temporally closer to the second tone (the auditory tau effect). Experiment 1 examined whether the auditory tau effect could be obtained in the case of speech and nonspeech. The results showed that in the case of the pitch of pure tones, the auditory tau effect occurs, in the case of the phonetic judgments of synthetic vowels, on the other hand, the second sound is perceived to be different from the sound that is temporally closer to the second sound (contrast), which is the reverse of the auditory tau effect. The results are interpreted on the basis of the availability of the auditory and categorical memories. Experiment 2 examined, using the auditory tau effect paradigm, the influence of the phonetic categories of the stimuli upon the production of assimilation and contrast. The results demonstrated that assimilation to the temporally closer sound occurs in the phonetic perception of vowels as long as the phonetic categories of the first and the third sounds are the same, although contrast occurs when the categories of vowels are different. This transition from assimilation to contrast was found to be continuous. It is suggested that the difference between speech and nonspeech might be caused by the psychological rather than the physical attributes of the stimuli.
\end{abstract}


Key words : the auditory tau effect, assimilation, contrast, auditory memory, categorical memory

\section{I .はじめに}

1950 年代からの音声合成器の開発により, 音声言語 の知覚心理実験は急速に進展した。言語音は非言語音 と物理的に同じ方法でその基本的特徵（例，大きさ， 高さなど）を記述することができるにもかかわらず, 異なる様式で知覚されることが認められている。この 点について，主に $2 つ$ つ対立する説が考えられている. 1 つは人間は音声に対して特殊な知覚機構を生得的に 有するとする考え方, 他の 1 つは音声の音響的特徵を 知覚する過程は, 非言語音を知覚する過程の組み合わ さったものであり, 音素のカテゴリーは本質的には音 声に特有なものではなく, 特定の聴覚的パターンに一 定のカテゴリーを割り当てたものであるとする考え方 である. Wood ${ }^{11}$ は, 言語音知覚に特有な処理過程が存 在することを示す現象として, カテゴリー知覚や両耳 分離聴における右耳の優位性などを挙げた。最近では, 文脈効果における同化と対比 ${ }^{2)}$ や知覚的統合 ${ }^{3)}$ な゙の 現象において, 言語音と非言語音の知覚に差異のある ことが報告されている4).

このような知覚実験の結果に対して, 音声言語の知 覚が生成面からの制約を受けること卢や, 特徵検出器6) などの言語音知覚に特有な生理的・知覚的機構を仮定 した説明が与えられてきた。しかし生得的な処理機構 の仮定は生理学的根拠に乏しく, 確定的ではない。一 方, 知覚判断する際のきき手の記憶機構や知覚様式な どの問題も重要である7).

以上の点を考慮すると, 検討すべき問題点としては, 刺激音の選び方, 判断の様式, 生成と知覚, 空間 (例, フォルマント周波数の高さ）と時間の統合などの問題 が残されている。そこで，次に著者が最近行った心理 実験の例を $2 つ$ づて, これらの問題点について考察 する。

\section{II. 聴覚的タウ効果における言語音と非言語音の 知覚 ${ }^{8)}$ (実験 1 )}

\section{1. 目 的}

刺激音の空間情報（例, 高さなど）についての知覚 が，時間情報（刺激音の提示時間間隔情報）の影響を 受けて，判断が同化を示す（時間的に接近した音への 類似判断が増加する) 現象は，「聴覚的夕ウ効果」とし て知られている。本実験では空間情報として, 純音の 高さ判断と母音の音韻判断の 2 つの場合を取り上げ,
聴覚的夕ウ効果における言語音 (母音) と非言語音 (純 音）の知覚にどのような差異がみられるのかを調べる ことを目的とする。

\section{2. 方 法}

1) 被験者：聴覚が正常で日本語を母国語とする大 学生を用いた。すべて合成音の聴取やこの種の聴覚心 理実験に参加した経験を有しない. 純音の実験には 7 名，合成母音の実験には 20 名を用いた。

2 ) 刺 激：純音と合成母音を刺激に選んだ。純音 の作成には, 聴覚的夕ウ効果についてのこれまでの研

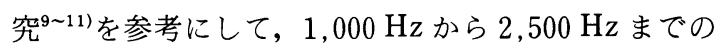
範囲を選び, 第 1 音は $1,000 \mathrm{~Hz}$ に, 第 3 音は $2,500 \mathrm{~Hz}$ に一定とした。第 2 音はその間に $100 \mathrm{~Hz}$ 間隔に 1,350 $\mathrm{Hz}$ から, $2,150 \mathrm{~Hz}$ まで 9 種類に変化させ, 第 1 音, 第 3 音とランダムに組み合わせた。

合成母音の場合には，日本語の典型的な母音/e/と /i/を選んだ。具体的なパラメー夕は表 1 に示す. 第 2 音は/e/と/i/の間で第 1 , 第 2 , 第 3 フォルマント周波 数 $\left(\mathrm{F}_{1}, \mathrm{~F}_{2}, \mathrm{~F}_{3}\right)$ を直線的に変化させて作成した。他の

表 1 実験 1 に用いた刺激音の $F_{1}, F_{2}, F_{3}$ の値(単位 は $\mathrm{Hz}$ )

\begin{tabular}{rccc}
\hline \multicolumn{2}{c}{ Stimulus } & \multicolumn{3}{c}{ Formant frequencies $(\mathrm{Hz})$} \\
number & $\mathrm{F}_{1}$ & $\mathrm{~F}_{2}$ & $\mathrm{~F}_{3}$ \\
\hline / i / 1 & 300 & 2500 & 2800 \\
2 & 350 & 2360 & 2760 \\
3 & 370 & 2310 & 2740 \\
4 & 390 & 2260 & 2720 \\
5 & 410 & 2210 & 2700 \\
6 & 430 & 2160 & 2680 \\
7 & 450 & 2110 & 2660 \\
8 & 470 & 2060 & 2640 \\
/ e / 9 & 520 & 1920 & 2600 \\
\hline / i / 10 & 270 & 2140 & 2780 \\
11 & 300 & 2140 & 2780 \\
12 & 310 & 2140 & 2780 \\
13 & 320 & 2140 & 2780 \\
14 & 330 & 2140 & 2780 \\
15 & 340 & 2140 & 2780 \\
16 & 350 & 2140 & 2780 \\
17 & 360 & 2140 & 2780 \\
/ I / 18 & 390 & 2140 & 2780 \\
\hline
\end{tabular}


值はすべて一定とした.すなわち, $\mathrm{F}_{0}=140 \mathrm{~Hz}, \mathrm{~F}_{4}=3$, $500 \mathrm{~Hz}, \mathrm{~F}_{5}=4,500 \mathrm{~Hz}, \mathrm{~B}_{1}=60 \mathrm{~Hz}, \mathrm{~B}_{2}=100 \mathrm{~Hz}, \mathrm{~B}_{3}=$ $120 \mathrm{~Hz}, \mathrm{~B}_{4}=175 \mathrm{~Hz}, \mathrm{~B}_{5}=280 \mathrm{~Hz}$ とした.

刺激の持続時間はすべて $200 \mathrm{msec}$ 一定とし, クリ

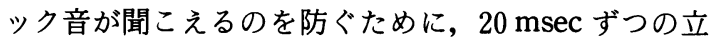
ち上がり，立ち下がりをつけた。

刺激音の作成は電子計算機（PDP11）を用いたが, 特に合成母音の場合には， 5 極の直列ターミナルアナ ログ方式の計算機シミュレーションによった. 刺激音 はすべて, 精度 10 ビット, 標本化周波数 $10 \mathrm{kHz} て ゙$ $\mathrm{D} / \mathrm{A}$ 変換し, $4.5 \mathrm{kHz}$ のローパスフィル夕を通して オフライン実験用にテープに録音した。刺激音はすべ て最大振幅による正規化を行い, 実効值が一定となる ようにした。

3) 手続き：提示方法は AXB 法による恒常法を用 いた。 AXB 法は, 図 1 に示すょうに, 3 つの音 $\mathrm{A}, \mathrm{X}$, $\mathrm{B}$ を継時的に提示し, $\mathrm{X}$ についての判断を求める方法 である. 提示時間間隔 $\mathrm{t}_{1}$ と $\mathrm{t}_{2}$ の関係は, その和が常に $1000 \mathrm{msec}(1 \mathrm{sec})$ になるようにして, $50 \mathrm{msec}$ と 950

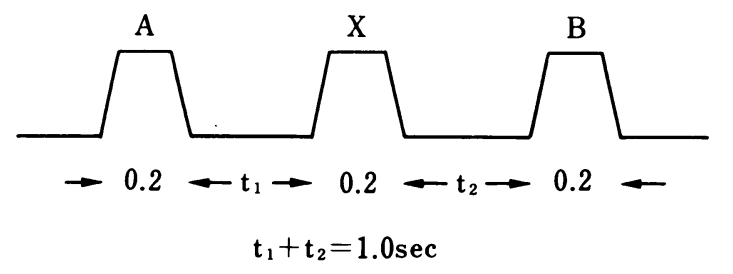

図 $1 \mathrm{AXB}$ 法における刺激音の提示方法

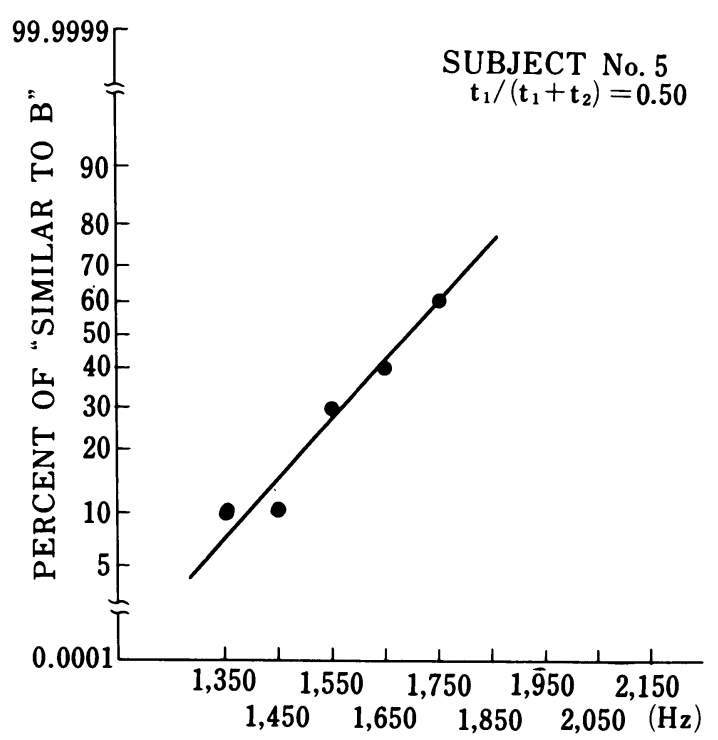

図 2 正規グラフ法によるデータの処理の例 （純音の場合） $\mathrm{msec}, 250 \mathrm{msec}$ と $750 \mathrm{msec}, 500 \mathrm{msec}$ と $500 \mathrm{msec}$, $750 \mathrm{msec}$ と $250 \mathrm{msec}, 950 \mathrm{msec} と 50 \mathrm{msec}$ の 5 条件 を選んだ. 刺激音の提示はスピーカを通して行い,「X は A または B のどちらにより似ているか」という判 断を, 1 刺激音につき被験者一人当りから, 純音の場 合は 10 回, 合成母音の場合は 8 回得た。

\section{3. 結 果}

実験結果は, X を B により似ているとする判断数が $\mathrm{X}$ の周波数（または $\mathrm{F}_{1}$ ) の高さに応じて累積正規分布 をすると仮定して, 正規グラフ法により被験者毎の処 理をし(図 2 はその 1 例), 平均值と標準偏差を求めた。 平均值は $\mathrm{A}$ と $\mathrm{B}$ の丁度まん中の高さに聞こえる X の 周波数值（または $\mathrm{F}_{1}$ 值）を表し, 調整法で得られる主 観的等価值 (PSE) に相当する. 標準偏差は判断のバ ラツキを表す。

さらに純音, 合成母音の場合ともそれぞれ, 全被験 者の判断をプールした結果をミュラー・アーバンの重 み付を用いた最尤法により処理をし, 平均値と標準偏 差を求めた. 図 3 は純音の結果をグラフに表したもの であり, 図 4 は合成母音の結果をグラフに表したもの である. 図 3 では, X が A に時間的に接近している場 合には平均值は高い值になる（X を低く聞きやすい） が, $\mathrm{X}$ が B に時間的に接近している場合には平均値は 低い值になる $(\mathrm{X}$ を高く聞きやすい)。したがって, 時 間的に接近する音の方へ高さが同化的に判断されてお り, 聴覚的夕ウ効果と全く同じ現象が生起しているこ とが明瞭に認められた。極端な同化を示す被験者一人

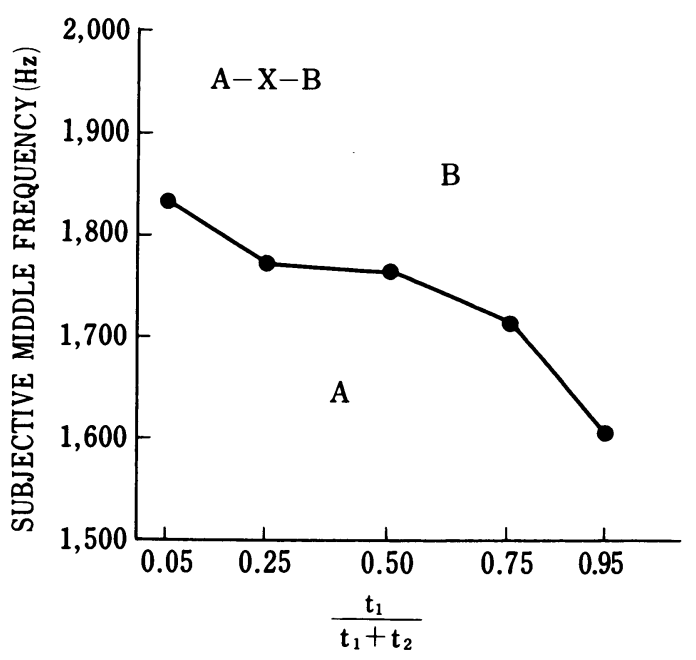

図 3 純音を用いた場合のプールした結果（聴覚的 タウ効果). 横軸は時間条件, 縦軸は $\mathrm{A}$ と $\mathrm{B}$ の丁度まん中の高さにきこえるX の周波数 值を表す 
のデータを除いて $\mathrm{t}$ 検定を行うと, $\mathrm{t}_{1}=50 \mathrm{msec} と \mathrm{t}_{1}=$ $950 \mathrm{msec}$ との間で有意な差が認められた $[\mathrm{t}(5)=$ $4.319, \mathrm{p}<0.01]$.

図 4 では,/e/-x-/i/の場合には X は/e/に時間的に 接近すると $\mathrm{X}$ を/i/に聞きやすくカテゴリー境界值は 高くなるが, $\mathrm{X}$ が/i/に時間的に接近すると X を/e/に 聞きやすくカテゴリー境界值は低くなり，時間的に接 近した音への対比を示す $\left[\mathrm{t}_{1}=50 \mathrm{msec}\right.$ と $\mathrm{t}_{1}=950$ $\mathrm{msec}$ との間で, $\mathrm{t}(5)=4.89, \mathrm{p}<0.01] . / \mathrm{i} /-\mathrm{X}-/ \mathrm{e} /$ の 場合についても同様である $[\mathrm{t}(5)=2.69, \mathrm{p}<0.05]$. したがって, 聴覚的夕ウ効果とは反対に, 時間的に接 近する音への対比が生起したことを表している．この 現象を本研究では夕ウ効果と対照させて「逆夕ウ効果」 と呼ぶことにする．逆夕ウ効果は 3 音を継時的に提示 する場合, 第 2 音の知覚が時間的に接近する音に対し て対比的に知覚される現象である。ただし，2つの系 列の間で結果は対称的ではなく,/e/-X-/i/系列の方 がこの効果は大きい.

\section{4. 考 察}

本実験では純音の知覚においては，時間的に接近す る音に対する同化が認められた。一方，3つの音を日 常会話で異なる音素として聞いている合成母音の知覚 においては，このような傾向は全く認められず，逆に 接近する音に対して対比的に判断が変容することが明 らかになった。

音韻の知覚が時間要因から受ける影響は，音韻情報 を保持する短期記憶の種類や特性と関連していると考 えられる ${ }^{12)}$. 純音の高さについて類似性判断を求めら
れた場合, 被験者は聴覚的短期記憶にその高さについ ての情報を順次保持し, 最終的には刺激連続体（周波 数）に対応して形成されるピッチという心理学的連続 体上での距離関係によって, 判断が下されると考えら れる，一方，母音の場合にも韻質（音色）に関して心 理学的連続体へのプロットが行われるが，母音のよう にそのカテゴリー境界が長い期間にわたり学習されて いる刺激に関して類似性判断が求められた場合には, カテゴリーへの同定が刺激音の提示とほほ同時に下さ れ，それがカテゴリー的短期記憶に保持されて類似性 判断に用いられると推定される。この場合, ぞれくら い音色が似ているかを判断するよりも，カテゴリーの 同・異を判断する方が容易であるから，結局 3 つの音 の間で「第 2 音は第 1 音と第 3 音のどちらのカテゴリ 一と同じであるか」というカテゴリーの比較が行われ, カテゴリー判断の結果がまず優先して類似性判断に用 いられると考えられる.このことが, / i/と/e/のように 異なるカテゴリーの母音間では，純音の場合とは反対 に, X の知覚は時間的に接近する刺激音に対して対比 を示す要因になると考えられる。

以上の考え方では，同化が生起するか対比が生起す るかの違いは，聴覚的およびカテゴリー的のどちらの 短期記憶からの情報が優先的に用いられるかによると 考えられ，聴覚的記憶に基づいて類似性判断が行われ る場合には同化が，カテゴリー的記憶に基づいて類似 性判断が行われる場合には対比が生起すると考えられ る.さらに，同種類の短期記憶の間では時間的に接近 する方が時間的に隔たる方よりも保持している情報量
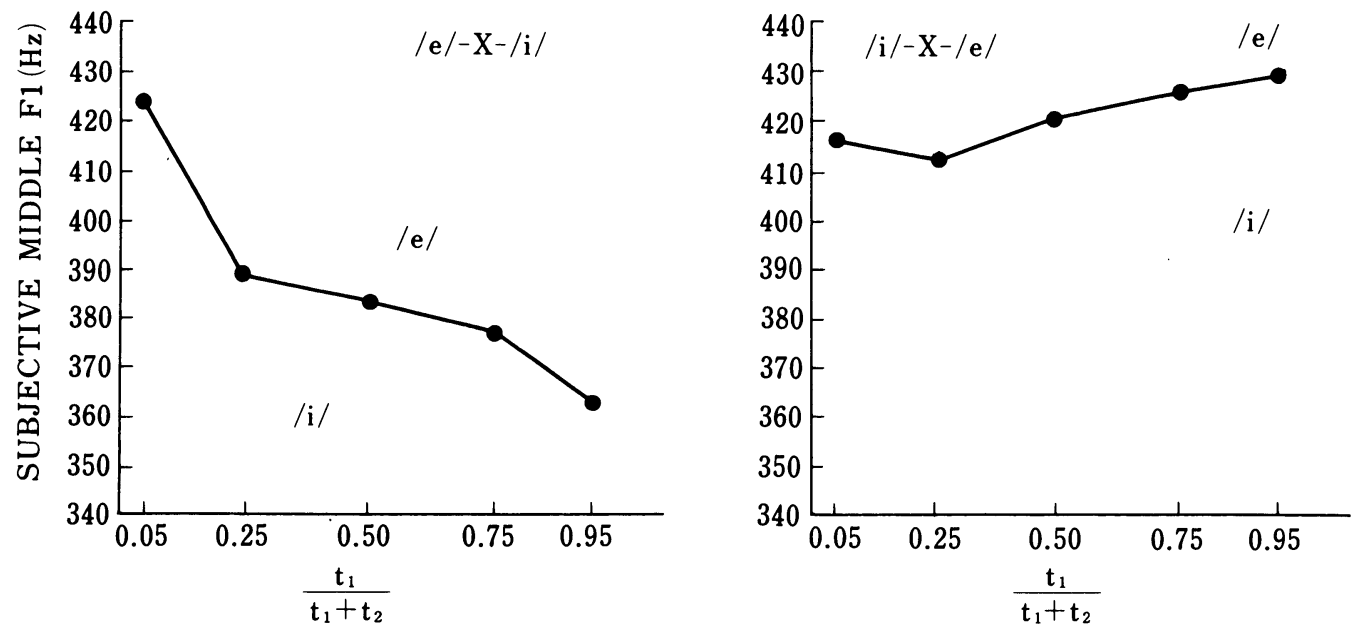

図 4 合成母音を用いた場合のプールした結果（逆夕ウ効果）。横軸は時間条件，縦軸は第 1 音と第 3 音の 間のカテゴリー境界を $F_{1}$ 值で表示したもの 
が多く，そのためまん中の音が時間的に接近する音に 対して示す同化ないし対比の大きさは, 接近すればす るほど大きくなると考えられる。

カテゴリー知覚の研究にしばしば用いられた $\mathrm{ABX}$ 法は弁別判断を求める方法であったが，そこでの刺激 の情報処理の方法は本研究で用いた AXB 法による類 似性判断とほほ同じであると考えられる. 本実験で用 いた AXB 法の場合には，強制的に韻質についての心 理学的連続体上での距離の比較を行わせようとしたも のであるが, 結局はカテゴリー的情報と䫓質について の聴覚的な情報の間で, 択一的に情報が取捨されるこ とを示唆している.

Cohen et al. ${ }^{11)}$ （1974）は純音の場合，上昇系列と下 降系列の間では対称的な結果が得られるとしたが，本 実験の結果では A，Bを入れ換えた系列において結果 は対称的にはならなかった。母音の知覚は，音素の種 類によって文脈効果の大きさが異なることが知られて いる ${ }^{13)}$. したがって,/i/,/e/はそれぞれ第 1 音, 第 3 音 として提示された場合，第 2 音 $(\mathrm{X})$ に対して等しい効 果を及ぼすのではなく，どちらかの音素からの方が影 響が大きいために, 非対称な結果になると考えられる。 なお, 本実験では/i/と/e/の組み合わせを用いたが, 第 2 フォルマント周波数の変化だけで識別できる/u/ と/i/の組み合せを用いて $/ \mathrm{u} /-\mathrm{X}-/ \mathrm{i} /$ 系列について同様 の実験を行って調べると, $/ \mathrm{u} /-\mathrm{X}-/ \mathrm{i} /$ 系列では Xが第 3 音に接近したときは対比が生起したが, 第 1 音に接 近したときはXは第 1 音に対してむしろ同化を生起し て, 聴覚的夕ウ効果も逆夕ウ効果も認められず, 全般 的に第 3 音 $(/ \mathrm{i} /)$ に対する対比が認められた ${ }^{14)}$. 音素 の間で同化や対比を生起させる影響力には大小があ

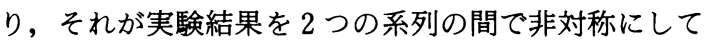
いると考えられる。しかし，どの音素の効果が大きい のか, またなぜ音素の間で影響力に大小があるのかに ついては，本実験からは明らかにされない。

\section{III. 同化・対比とカテゴリー判断の関係 ${ }^{15)}$ (実験 2 )}

\section{1. 目的}

実験 1 の結果より，時間的により接近した音の方へ 同化 (聴覚的夕ウ効果) が生起するか対比（逆夕ウ効 果）が生起するかは, 用いる刺激音の間のカテゴリー の同・異によることが示唆された．実験 1 の考察でも 述べたように，同化や対比が聴覚的情報とカテゴリー 的情報のなんらかの（例えば加算的な）統合によって 行われるとすれば，第 1 音と第 3 音の間のカテゴリー の同・異関係が同カテゴリーから異カテゴリーへと連 続的に変化する場合, 第 2 音の知覚も時間的に接近す
る音に対する同化から対比へと連続的に変化すること が予想される，すなわち，音色は連続量として記憶保 持が行われると考えられるので，言語音（母音）の知 覚においても，もし日常会話において同じカテゴリー の音として用いられている 3 音の場合には, わずかな 音色の違いすなわち韻質の違いを手がかりとして 3 音 間の比較が行われると考えられ，純音の場合と同様に 時間的に接近する音への同化（聴覚的夕ウ効果）が生 じることが予想される。

実験 2 は，以上の点について調べることを目的とす る. 具体的には, $/ \mathrm{i} /, / \mathrm{I} /, / \mathrm{e} /$ の 3 種類の母音の間で, 3 つの音の組み合わせを同カテゴリー条件から異カテゴ リ一条件へと連続的に変化させ，第 2 音の知覚が時間 的に接近する音への同化から対比へと連続的に変化す るかどうかについて調べる。

2. 方 法

1) 被験者：聴覚の正常な大学生 6 名. 全員女性て あり，右利きであった。また，合成音の聴取実験に参 加した経験は有していない.

2 ) 刺 激 : 刺激音は, 日本語の典型的な母音/i/と /e/およびそれらの中間の母音/I/を用いた。/I/は日本 語ではふつう 1 つの母音として独立して用られること はない，合成母音の同定実験の例を見ると，日本語で は/I/はふつう/i/と同じカテゴリーに入れられる が $^{16)}$ ，音色は異なって知覚されることが認められてい る。本実験では, / i/と/I/を組み合わせた場合を「同力

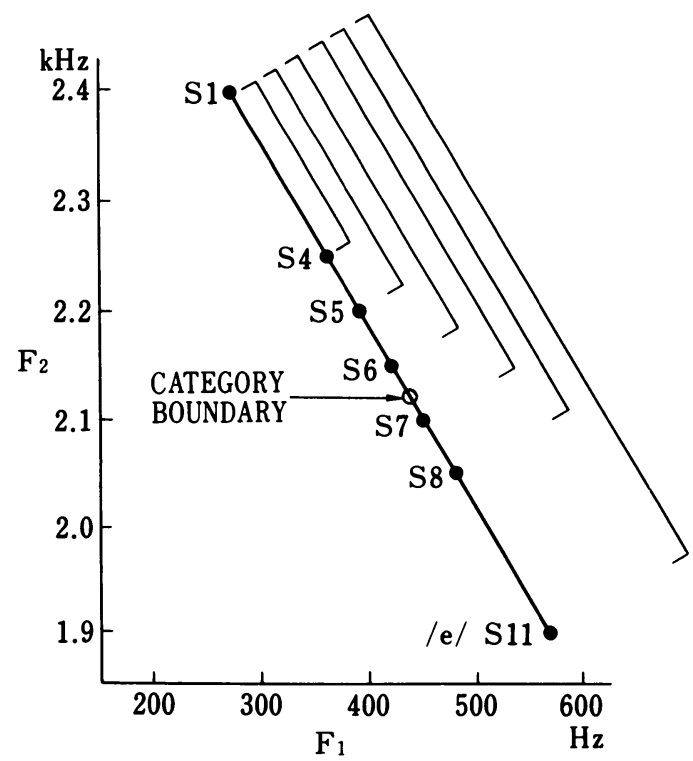

图 5 実験 2 に用いた合成母音の標準刺激（S1, S4, S5, S6, S7, S8, S11) と対象刺激の刺激連続 体 $\left(\mathrm{F}_{1}-\mathrm{F}_{2}\right.$ 平面上 $)$ 
テゴリー条件」と呼び, $/ \mathrm{i} /$ と/e/を組み合わせた場合を 「異カテゴリー条件」と呼んで区別する。刺激音の組み 合わせは, $\mathrm{F}_{1}-\mathrm{F}_{2}$ 平面上で/i/ $\left(\mathrm{F}_{1}=270 \mathrm{~Hz}, \mathrm{~F}_{2}=2\right.$, $\left.400 \mathrm{~Hz}, \mathrm{~F}_{3}=2,800 \mathrm{~Hz}\right)$ と $/ \mathrm{e} /\left(\mathrm{F}_{1}=570 \mathrm{~Hz}, \mathrm{~F}_{2}=1,900 \mathrm{~Hz}\right.$, $\mathrm{F}_{3}=2,600 \mathrm{~Hz}$ ) を結ぶ直線的な連続体上に 6 種類選ん だ（図 5 ）。すなわち，第 1 音と第 3 音（ともに標準刺 激）が同じカテゴリーに属する S4-S1（同カテゴリー 条件)から, 両端が異なるカテゴリーに属する S11-S1 (異カテゴリー条件) までの 6 種類である. 対象刺激は 第 1 音と第 3 音の間に 7 種類選んだ．以上の刺激音の 具体的なパラメー夕は表 2 に, 各刺激系列における対 象刺激の範囲は表 3 に示す。これらの刺激音はあらか じめ行った/i/-/e/の同定実験から得た結果 $(/ \mathrm{i} /$ と/e/ の音素境界は刺激番号 6.60 であった) を参考にして決 定した。その他のパラメー夕は， $\mathrm{F}_{0}=140 \mathrm{~Hz}, \mathrm{~F}_{4}=3$, $500 \mathrm{~Hz}, \mathrm{~F}_{5}=4,500 \mathrm{~Hz}, \mathrm{~F}_{6}=4,999 \mathrm{~Hz}, \mathrm{~B}_{1}=60 \mathrm{~Hz}, \mathrm{~B}_{2}=$ $100 \mathrm{~Hz}, \mathrm{~B}_{3}=120 \mathrm{~Hz}, \mathrm{~B}_{4}=175 \mathrm{~Hz}, \mathrm{~B}_{5}=280 \mathrm{~Hz}, \mathrm{~B}_{6}=1$, $000 \mathrm{~Hz}$ とした。

刺激音の持続時間はすべて $100 \mathrm{msec}$ 一定とし, 10 $\mathrm{msec}$ の立ち上がり, 立ち下がり時間を与えた。

刺激音は電子計算機 (VAX 11) を用い，6極の直列 ターミナルアナログ型合成器のシミュレーションによ り合成し, 精度 12 ビット, 標本化周波数 $10 \mathrm{kHz}$ でD/

表 2 実験 2 に用いた標準刺激 $(\mathrm{S} 1-\mathrm{S} 11)$ の $\mathrm{F}_{1}, \mathrm{~F}_{2}$, $\mathrm{F}_{3}$ の值(単位は $\mathrm{Hz}$ )

\begin{tabular}{c|c|ccc}
\hline File name & $\begin{array}{c}\text { Stimulus } \\
\text { number }\end{array}$ & $\mathrm{F}_{1}$ & $\begin{array}{c}\mathrm{F}_{2} \\
(\mathrm{~Hz})\end{array}$ & $\mathrm{F}_{3}$ \\
\hline S 1 & 1 & 270 & 2400 & 2800 \\
S 4 & 4 & 360 & 2250 & 2740 \\
S5 & 5 & 390 & 2200 & 2720 \\
S6 & 6 & 420 & 2150 & 2700 \\
S 7 & 7 & 450 & 2100 & 2680 \\
S8 & 8 & 480 & 2050 & 2660 \\
S 11 & 11 & 570 & 1900 & 2600 \\
\hline
\end{tabular}

表 3 実験 2 に用いた対象刺激 $(\mathrm{X})$ の範囲, $\mathrm{F}_{2}, \mathrm{~F}_{3}$ は $\mathrm{F}_{1}$ にあわせて比例計算した(単位は $\mathrm{Hz}$ )

\begin{tabular}{c|c|c|c|c}
\hline Series & $\mathrm{F}_{1}$ & $\Delta \mathrm{F}_{1}$ & $\mathrm{~F}_{2}$ & $\mathrm{~F}_{3}$ \\
\hline S4-S1 & $285-345$ & 10 & $2375-2275$ & $2790-2750$ \\
S5-S1 & $300-360$ & 10 & $2350-2740$ & $2780-2740$ \\
S6-S1 & $300-390$ & 15 & $2350-2192$ & $2780-2720$ \\
S7-S1 & $300-420$ & 20 & $2350-2150$ & $2780-2700$ \\
S8-S1 & $315-435$ & 20 & $2325-2125$ & $2770-2690$ \\
S11-S1 & $345-495$ & 25 & $2275-2025$ & $2275-2650$ \\
\hline
\end{tabular}

$\mathrm{A}$ 変換し, $4.5 \mathrm{kHz}$ のローパスフィル夕を通して録音 した。その他の方法は，実験 1 と同様であった。

3 ) 手続き: 刺激音の提示は, 実験 1 と同様に AXB 法を用いた。提示時間間隔 $t_{1}$ ( $A$ とXの間) と $t_{2}(X$ と Bの間) の関係はその和が常に $1,000 \mathrm{msec}(1 \mathrm{sec})$ になるようにして, $50 \mathrm{msec}$ と $950 \mathrm{msec}, 500 \mathrm{msec}$ と $500 \mathrm{msec}, 950 \mathrm{msec}$ と $50 \mathrm{msec} の 3$ 条件とした。これ は実験 1 の時間条件から $250 \mathrm{msec}$ と $750 \mathrm{msec}, 750$ $\mathrm{msec}$ と $250 \mathrm{msec}$ の 2 条件を減らして 3 条件にした ものである.

刺激音の提示は約 $78 \mathrm{~dB}$ (c) でスピーカを通して行

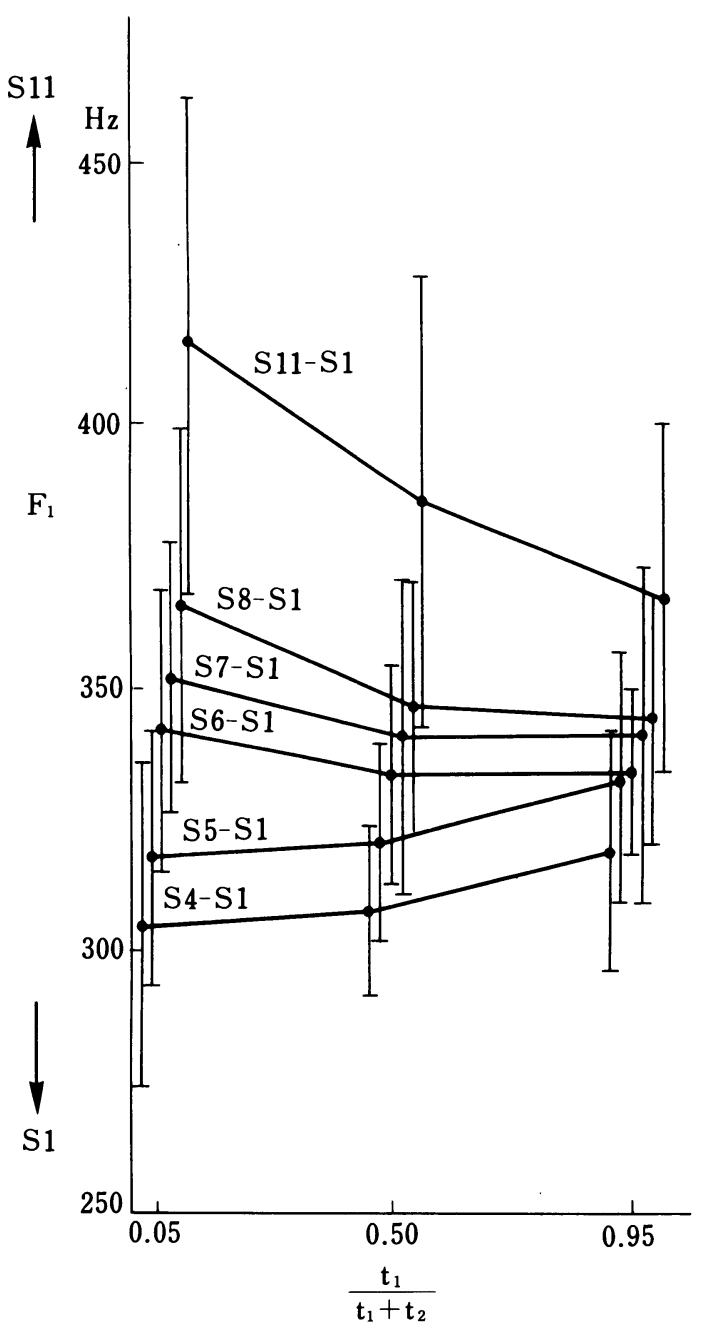

図 6 実験 2 のプールした結果から得た平均值（カ テゴリー境界) と標準偏差. 図中の折れ線は, $\mathrm{S} 4$-S1 から S11-S1 までの 6 つの組み合わ せ条件毎の結果を表す 
った。「XはAまたはBのどちらにより似ているか」と いう類似性判断を， 1 刺激音につき被験者 1 人当り 10 回得た。

\section{3. 結 果}

実験結果は, 実験 1 と同様の前提のもとに処理を行 い, 被験者毎の平均值と標準偏差，およびプールした 結果の平均値と標準偏差を求めた。図 6 はプールした 結果をグラフに表したものである。横軸は 3 種類の時 間間隔の条件を $\mathrm{t}_{1} /\left(\mathrm{t}_{1}+\mathrm{t}_{2}\right)$ の值で表したものであり， 縦軸は $F_{1}$ を表している. 右上がりの折れ線は時間的に 接近した音への同化（聴覚的夕ウ効果）が生起したこ とを示しているのに対して，右下がりの折れ線は対比 (逆夕ウ効果)が生起したことを示している.グラフは, 2 つの標準刺激（第 1 音と第 3 音）が同カテゴリー条 件から異カテゴリー条件へと移り変わるのに応じて, 時間的に接近する音に対する同化から対比へと対象刺 激（第 2 音）の知覚も連続的に変化している様子を明 瞭に示している.

$\mathrm{S} 5-\mathrm{S} 1$ と $\mathrm{S} 6-\mathrm{S} 1$ の 2 本の折れ線の間で，折れ線が右 上がりから右下がりへと逆転しており，この間あたり に同化から対比への変換点があるらしい．また標準偏 差は同カテゴリー条件よりも異カテゴリー条件になる につれて大きくなる傾向があるが，これはステップ間 隔が異カテゴリー条件の方が大きかったためであると 考えられる。 $\mathrm{t}_{1} /\left(\mathrm{t}_{1}+\mathrm{t}_{2}\right)$ が 0.05 の場合のカテゴリー境 界値と 0.95 の場合のカテゴリー境界值の間の移動量 の差を S5-S1 と S6-S1 の間で $\mathrm{t}$ 検定すると, $\mathrm{t}(3)=$ 2.438, $\mathrm{p}<0.05$ で有意差があった. ただし，極端な同 化や対比を示した 2 人のデー夕は検定から除外した。

\section{4. 考 察}

実験結果から，時間的に接近する音への同化と対比 は刺激連続体の拡大にともない連続的に変化し，2つ の音素のカテゴリー境界付近にその変換点のあること がわかったすすなわち，第 1 音と第 3 音（ともに標準 刺激）のカテゴリー境界をはさんで第 2 音の知覚は時 間的に接近した音への同化から対比を示すように連続 的に変化する。このように刺激音の属性に応じて時間 間隔の変化が刺激音の知覚を同化や対比に変容させる ことから，知覚が時間条件から受ける影響は刺激属性 によって異なることが示唆された。

同カテゴリー条件の場合には，3つの音の間の比較 にカテゴリー情報を利用しにくく，カテゴリーの情報 よりも聴覚的情報の方が優先的に利用されやすいと考 えられる。この場合，カテゴリー情報が利用しにくい 理由としては，1つにはカテゴリー判断が行われる程 度はカテゴリー境界の習得度によって異なり，その習
得度が低い場合にはカテゴリー判断は行われにくく時 間がかかること，また 3 つの音がすべて同じカテゴリ 一である場合には，カテゴリー情報をもとに類似性判 断を下すことができない，という点が考えられる。し たがって同カテゴリー条件では，聴覚的短期記憶にそ の韻質についての情報が順次保持され，韻質について の心理学的連続体上での比較判断が下されると考えら れる，その結果，純音と同様の結果すなわち時間的に 接近する音に対する同化が生じると考えられる。

同化から対比へと知覚が連続的に変化するというこ とは, 同化を生起させる要因と対比を生起させる要因 が， 2 者択一的に入れ替わるのではなく，類似性判断 に及ほすをれぞれの要因の相対的な大きさが徐々に変 化したためと考えるのが自然であろう。実験 1 の結果 からも推測されたように，2つの要因としては聴覚的 短期記憶とカテゴリー的短期記憶が考えられる．同化 は聴覚的記憶に保持されている情報が類似性判断に利 用される場合に生じ，対比はカテゴリー的記憶に保持 されている情報が類似性判断に利用される場合に生じ るとする実験 1 の仮説は, 本実験の結果にも適用する ことができる．すなわち，用いる 3 つの刺激音の関係 が同カテゴリー条件の場合には, 刺激連続体上での $\mathrm{AX}$ 間と XB 間の距離の比較を用い, 異カテゴリー条 件の場合には $\mathrm{A}, \mathrm{X}, \mathrm{B}$ 各々の音素名の同異によって 判断が行われると考えられる。そして，刺激音が同力 テゴリー条件から異カテゴリ一条件へと連続的に変化 するのに応じて，2つの短期記憶に保持されている情 報が類似性判断に利用される相対的な大きさが連続的 に変化し, 第 2 音 $(\mathrm{X})$ の知覚が同化から対比へと連続 的に変化すると考えられる。

同カテゴリー条件では同化的に, 異カテゴリー条件 では対比的に聞こえやすいという本実験で得られた結 果はまた，同じカテゴリー内の母音は同カテゴリーと してきき，異なるカテゴリー間の母音はその違いを対 比によって強調してきくことにより，日常会話におけ る暧昧な発話を聴覚的に補償していることを示すもの とも考えられる。

\section{V，言語音・非言語音の知覚}

本研究の中で行った $2 つ の$ 実験から得られた主な結 果を, 以下に要約する.

1） 3 音の継時提示において，第 2 音が時間的に接 近する音へ同化して知覚される聴覚的夕ウ効果は, 純 音のピッチ判断だけではなく, 同カテゴリー条件の母

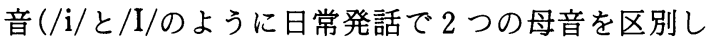
ない場合）においても生起する。 
2 ) 異カテゴリー条件 (/i/と/e/) の母音の知覚にお いては, 時間的に接近する音へ対比の生起することが 認められた。そこでこれを「逆夕ウ効果」と名付けた。

3 ）母音の場合, 同カテゴリー条件から異カテゴリ 一条件へと刺激が連続的に変化すると，知覚の方も同 化から対比へと連続的に変化する。

以上の結果をもとにして次に，聴覚的夕ウ効果や同 化・対比の問題を中心に, 言語信号とはどのようなも のに考えてゆけばよいのか, また言語音と非言語音の 知覚はいかなる過程をたどるのかを考察する.

本研究中での重要な発見の 1 つは, 時間的に接近す る音への同化（聴覚的夕ウ効果）が, 純音よりも複雑 な音である母音にまで生じる場合があり，また母音の 種類によっては正反対の結果, すなわち時間的に接近 する音への対比 (逆夕ウ効果) が生起することもある, ということである。ささらに, 聴覚的夕ウ効果は高さ知 覚に及ほす時間要因という時間効果ばかりでなく, 刺 激空間距離による距離効果も受け, 標準刺激のカテゴ リーの同・異関係が聴覚的夕ウ効果の生起の有無を決 定することも見出した。すすなわ，2つの標準刺激が /i/と/I/のように日常会話において同カテゴリーに属 する音であるなら，それらの間に音色の違いがあって も, 聴覚的夕ウ効果と同様に時間的に接近する音への 同化が認められた.しかし，2つの標準刺激が/i/の/e/ のように異なるカテゴリーに属する刺激である場合に は, 聴覚的夕ウ効果は生起せず, 代わりに時間的に接 近する音への対比（逆夕ウ効果）が生起した。このよ うな同化から対比への移り変わりは 2 つ標準刺激の カテゴリー関係の同・異の移り変わりとほほ対応して 連続的に生起し, 同化加ら対比への変換点はほほカテ ゴリー境界に一致した。時間効果と距離効果は互いに 独立的ではなく，両方の影響を受けて同化(聴覚的夕 ウ効果) や対比（逆夕ウ効果）が生起するのである.

言語音（母音）と非言語音 (純音) の知覚に認めら れた差異は，どのように説明されうるのか。言語音の 知覚が非言語音の知覚と異なるのは, 決して物理的性 質のみによるのでない，言語音の知覚には，生成面か らの制約が働くと考えられるが, 実験結果が直接的に 示しているのは, 別の要因である.すなわち, 音韻判 断の有無やカテゴリー判断の利用の程度などが考えら れる，音韻判断をしなければ，同化が生起しやすい. このことはすでに 2 音の例で報告されており, 例えば 音声言語を用いてそのピッチ判断をさせた場合には, 純音のピッチ判断の場合と同様に同化が生じやす い7).人はたとえ言語音を与えられても，それを言語音 としてきかなければ，非言語音と同じ知覚が行われる
と言えるのである.さらに, たとえ言語音としてきき, 音韻判断を行っても, 短期記憶に保持された情報が判 断に利用できる事態でなければ，対比は生じないと言 えるのである。逆に非言語音であっても，2つのカテ ゴリーが対立する場合であれば，言語音の場合と類似 の現象が生起する，このことはすでに，カテゴリー知 覚の例において認められている ${ }^{17,18)}$.このように考え ると, 言語音の知覚は, 音素カテゴリーへのカテゴリ 一化学習が習熟していること, 人が言語音としてきく という意図をもってきくこと，さらに音韻についての カテゴリー的記憶を知覚判断に利用すること, が重要 な規定要因であると考えられる。

\section{V.おわりに}

言語音と非言語音の知覚を比較することは各々の知 覚機構を知る上できわめて意義が大きい.そしてこれ まで多くの心理実験を通して，言語音と非言語音の受 聴における種々の共通点と相違点が明らかにされてい る。言語音と非言語音は物理的性質が異なることや, 言語音の場合には生成面からの制約といった問題がと もすれば強調されやすいようであるが，本研究では言 語音と非言語音の受聴とは, 結局, きく側がどのよう に刺激と関わるかという要因が大前提となることを示 した.

\section{文献}

1) Wood, C. C. : Auditory and phonetic levels of processing in speech perception : Neurophysiological and information processing analyses. Journal of the Experimental psychology : Human Perception and Performance, 104 : 3-20, 1975.

2) Shigeno, S. and Fujisaki, H. : Effect of a preceding anchor upon the categorical judgment of speech and non-speech stimuli. Japanese Psychological Research, 21 : 165-173, 1979.

3) Liberman, A.M. : Duplex perception and integration of cues : Evidence that speech is different from nonspeech and similar to language. In Proceedings of the Ninth International Congress of Phonetic Sciences (Vol. 2) Copenhagen : University of Copenhagen, 1979.

4）重野 純：言語音・非言語音の知覚過程—文脈 効果を中心として—. 基礎心理学研究, 4:7587, 1985.

5) Liberman, A.M., Cooper, F. S., Harris, K.S., and 
MacNeilage, P.F. : A motor theory of speech perception. In Proceedings of the Speech Communication Seminar. Stockholm : Royal Institute of Technology, D3, 1962.

6) Eimas, P.D. and Corbit, J.D. : Selective adaptation of linguistic feature detectors. Cognitive Psychology, 4 : 99-109, 1973.

7）重野 純, 藤崎博也：前向性・後向性文脈効果の 比較. 心理学研究, $51: 287-290,1980$.

8) Shigeno, S. : The auditory tau and kappa effects for speech and nonspeech stimuli. Perception \& Psychophysics, 40 : 9-19, 1986.

9) Cohen, J., Hansel, C.E.M., and Sylvester, J.D. : Interdependence of temporal auditory judgments. Nature, $174: 642,1954$.

10) Christensen, I.P. and Huang, Y.L. : The auditory tau effect and memory for pitch. Perception \& Psychophysics, 26 : 489-494, 1979.

11) Cohen, J., Christensen, I.P., and Ono, A. : Influence of temporal intervals on comparative judgments of pitch : A study of subjective relativity. Tohoku Psychological Folia, 33 : 76-87, 1974.

12）藤崎博也, 川島崇子 : 合成音声の弁別と言語音知 覚機構のモデル。日本音響学会誌, $27: 453-462$, 1971.

13) Sawusch, J.R. and Nusbaum, H. C. : Contextual effects in vowel perception I : Anchor-induced contrast effects. Perception \& Psychophysics, $25: 292-302,1979$.

14）重野 純：言語音・非言語音の知覚における auditory tau 効果について.日本音響学会講演論文集, 1-4-14 : 241-242, 1984.

15) Shigeno, S. : The auditory tau effect for synthetic vowels. XXIV International Congress of Psychology, Sydney, 1988.

16) Fujisaki, H., Nakamura, N., and Yoshimune, K. : Analysis, normalization and recognition of sustained Japanese vowels. Journal of the Acoustical Society of Japan, 26 : 152-154, 1970.

17) Cutting, J.E. and Rosner, B.S. : Categories and boundaries in speech and music. Perception \& Psychophysics, 16 : 564-570, 1974.

18) Siegel, J.A. and Siegle, W. : Categorical perception of tonal intervals : Musicians can't tell sharp from flat. Perception \& Psychophysics, 21 : 399-407, 1977.

〈脚注〉本研究中の実験は, 昭和 61 年度文部省科学研究費の補 助を受けて行われた（奖励研究 A : 課題番号 61710083).

別刷請求先： 7228 神奈川県相模原市北里 1-15-1

北里大学教養部

重野 純 